\title{
Synthesis and evaluation of possible mechanism of anti nociceptive potential of novel 2-quinolone fused 3,5-pyrazolidinedione derivatives in experimental animal models
}

\author{
Abhishek TIWARI ${ }^{* a}$ and Anita SINGH ${ }^{b}$ \\ ${ }^{a}$ Devsthali Vidyapeeth College of Pharmacy, Lalpur, Rudrapur (U.S. Nagar), Uttrakhand, India \\ ${ }^{b}$ Department of Pharmacy, Bhimtal Campus, Kaumaun University, Nainital, Bhimtal, India
}

\begin{abstract}
In the present synthesis a series of 1-(1-methyl-2-oxo-1,2-dihydroquinolin-4-yl)-2-substituted phenylpyrazolidine-3,5-diones were prepared. By the reaction of N-methylbenzenamine with diethyl malonoate 4-hydroxy-1-methylquinolin-2(1H)-one were prepared, which on treatment with posphoryl chloride converted into 4-chloro-1-methylquinolin-2(1H)-one. Subsequently with substituted phenyl hydrazines 1-methyl-4-(2substitutedphenylhydrazinyl)quinolin-2(1H)-one were obtained, which on reaction with diethyl malonate gave 1(1-methyl-2-oxo-1,2-dihydroquinolin-4-yl)-2-substituted phenylpyrazolidine-3,5-diones. All structures were characterized by IR, ${ }^{1}$ HNMR \& mass spectrometry. Further all the synthesized compounds were evaluated for their anti-nociceptive activity in mice by Eddy's hot plate and acetic acid induced writhing response. All compounds have shown the activity. In hot plate model compounds QAA-04c and QAA-04d have given more activity than standard, whereas in case of acetic acid induced writhing model compounds QAA-04a and QAA04d have given significant analgesic activity which is comparable with the standard drug. Compound QAA-04b has shown least analgesic activity. Compound QAA-04a was almost equal in activity to the standard drug diclofenac sodium and was considered as the lead molecule.
\end{abstract}

Keywords: - N-methylbenzenamine, diethyl malonoate, Eddy's hot plate, anti-nociceptive activity

\section{Introduction}

2-Quinolone derivatives are an important class of nitrogen containing heterocycles and were reported to possess a wide spectrum of biological properties such as antibacterial [1], analgesic [2], anti-inflammatory [3], antifungal [4] and antimalarial activities [5]. Pyrazolidine 3,5 diones exhibit antibacterial, antifungal [6,7], Cox inhibition activity [8], anti-inflammatory, antipyretic, analgesic [9], antitubercular [10], antiviral [11], anti hypertensive [12], antiglaucoma 13], antioxidant [14], anti depressant, anxiolytic, neuroprotective [15], antimicrobial [16], cytotoxic, antiproliferative [17], antidiabetic [18], anti-Alzheimer [19] and anticancer [20].

Several methods have been reported in literature for the synthesis of pyrazoles. Most common method of pyrazole synthesis is the reaction between 1, 3-diketocompounds and hydrazine or hydrazine hydrate or substituted hydrazines [21]. Antipyretic action of a pyrazole derivative in human was discovered by Knorr, in 1884 and the compound was named "antipyrine".

Pyrazolones and 1-phenyl-pyrazolidine-3,5diones are the most important derivatives of pyrazole and are present as a basic moiety in a number of pharmaceutical compounds like phenylbutazone, oxyphenbutazone, butazolidine, antipyrine, amino-pyrine and novalgin. In the present study 2- quinolones were condensed with pyrazolidine 3,5 diones. All the synthesized compounds were evaluated for their anti-nociceptive activity in mice by Eddy's hot plate and acetic acid induced writhing response. From this study it was concluded that substituent with electron donating 
groups was active and 4 amino substituted compound was almost equal in activity to the standard drug diclofenac sodium.

\section{Experimental}

Fig.1 shows the scheme protocol for synthesis. Chemicals were procured from Merk, Loba Chem and Central Drug House (P) Ltd., India of laboratory grade for synthesis of title compounds. Melting points of the title compounds were recorded in open capillary tube in liquid paraffin bath as well as in precision melting point apparatus and were uncorrected.

Thin-layer chromatography was carried out to monitor the reactions using silica gel $G$ plates. Solvent system used throughout the experimental work for running TLC plates was toluene, ethyl acetate in the ratio of $3: 2$.

IR spectra were recorded by using $\mathrm{KBr}$ pellet technique on Shimadzu IR spectrophotometer.

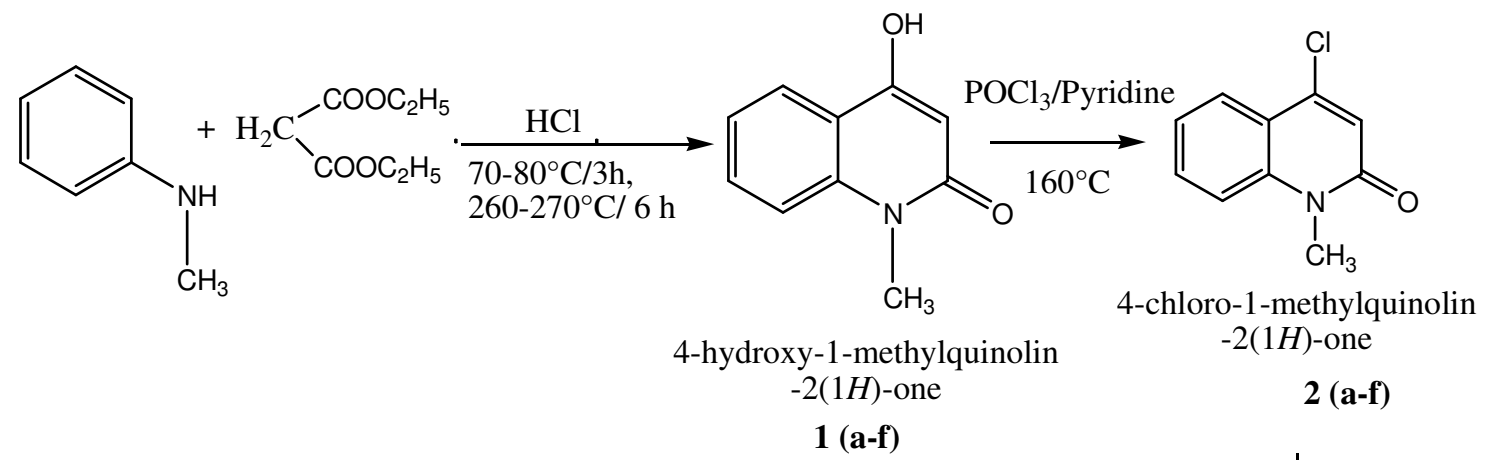<smiles>[R7]c1ccc(N2C(=O)CC(=O)N2c2cc(=O)n(C)c3ccccc23)cc1</smiles>

1-(1-methyl-2-oxo-1,2-dihydroquinolin-4-yl)2-substituted phenylpyrazolidine-3,5-dione

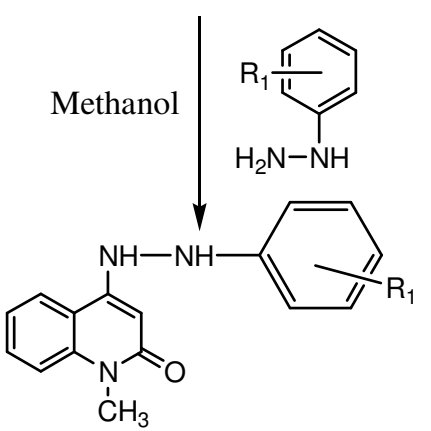

1-methyl-4-(2-substituted phenylhydrazinyl)quinolin-2(1H)-one

3 (a-f)

$4(\mathbf{a}-\mathbf{f})$

\section{$\mathrm{R} 1$ = 2-CH3, 4-CH3, 2-Cl, 4-Cl, 2, $4 \mathrm{Cl}, 2-\mathrm{NH} 2$ \& 4 NH2 SCHEME-I}

Fig.1. Protocol for synthesis of 1-(1-methyl-2-oxo-1,2-dihydroquinolin-4-yl)-2substituted phenylpyrayolidine-3,5-diones

${ }^{1}$ HNMR spectra were recorded in deuterated chloroform using tetra methyl silane (TMS) as an internal reference standard on Bruker Avance-II 400 NMR spectrometer and mass spectra were recorded on a thermo Finnegan LCQ advantage max ion trap mass spectrometer for title compounds. Spectral data were consistent with the assigned structures. 
2.1 General procedure for Synthesis of 4hydroxy-1-methylquinolin-2(1H)-one 1 (a-i) [22]

A mixture of $\mathrm{N}$-methylbenzeamine $(12 \mathrm{~g}, 0.07$ mol), diethyl malonate $(13 \mathrm{~mL}, 0.1 \mathrm{~mol})$, Dioxane $(25 \mathrm{~mL})$ and trace of conc. $\mathrm{HCl}$ was taken in $250 \mathrm{~mL}$ $\mathrm{RBF}$ and refluxed at $70-80^{\circ} \mathrm{C}$ for $3 \mathrm{~h}$ and then at 260 $270{ }^{\circ} \mathrm{C}$ for $6 \mathrm{~h}$ (until the distillation of ethanol stopped), cooled at room temperature and conc. sulfuric acid $(20 \mathrm{~mL})$ added. The mixture was refluxed at $190-200^{\circ} \mathrm{C}$ for $1 \mathrm{hr}$ and hot mixture was poured in $500 \mathrm{~mL}$ of ice cold water with constant stirring (Scheme 1).

Separated solid was filtered, dried, and recrystallized from ethanol. The yield of the product $\&$ m.p. was found to be $64.9 \%, 223-224^{\circ} \mathrm{C}$.

\subsection{General procedure for Synthesis of 4-chloro-1-} methylquinolin-2(1H)-one 2(a-i) [23]

In a $150 \mathrm{~mL}$ RBF was added the 4-hydroxy-1methylquinolin-2(1H)-one $(11.58 \mathrm{~g}, 0.6$ moles $), \mathrm{POCl}_{3}$ (9.2g, 0.6 moles) and pyridine $(2.37 \mathrm{~mL}, 0.03$ moles $)$. The reaction mixture was heated to $160{ }^{\circ} \mathrm{C}$ for 2 hours. After cooling, the contents were quenched with cold water $\left(\sim 0{ }^{\circ} \mathrm{C}, 100 \mathrm{~mL}\right)$, and the solution's $\mathrm{pH}$ was adjusted to $8-9$ with saturated $\mathrm{Na}_{2} \mathrm{CO}_{3}$ solution (Scheme 1).

Solid products were collected after filtration, and washing with a small amount of methyl $t$-butyl ether, and dried. . The yield of the product $\&$ m.p. was found to be $68.5 \%$. \& $245-247^{\circ} \mathrm{C}$.

2.3 General procedure for Synthesis of 1-methyl-4-(2substitutedphenyl hydrazinyl) quinolin-2(1H)-one 3 (a-i) [24]

To a suspension of 4-chloro-1-methylquinolin$2(1 \mathrm{H})$-one $2(\mathrm{a}-\mathrm{i})(6 \mathrm{~g}, 0.026 \mathrm{~mol})$ in methanol $(10 \mathrm{~mL})$ added phenyl hydrazine $(6 \mathrm{ml}, 0.05 \mathrm{~mol})$ at room temperature. After stirring, ethanol $(20 \mathrm{~mL})$ was added and refluxed for $1 \mathrm{hr}$, cooled at room temperature, filtered and washed the solid with diethyl ether (20 $\mathrm{mL}$ ) and purified from ethanol (Scheme 1).

The yield of the product $\&$ m.p. was found to be $75.8 \%$ \& $168-169^{\circ} \mathrm{C}$.

2.4 General procedure for Synthesis of 1-(1-methyl-2oxo-1,2-dihydroquinolin-4-yl)-2-substituted phenylpyrazolidine -3,5-diones 4(a-i) [25]

To a mixture of 1-methyl-4-(2-substituted phenyl hydrazinyl) quinolin-2(1H)-one 3 (a-i) $(6 \mathrm{~g}, 0.01 \mathrm{~mol})$ and diethyl malonate $(3 \mathrm{~mL}, 0.015 \mathrm{~mol})$ added ethanol $(90 \mathrm{~mL})$ and acetic acid $(1 \mathrm{~mL})$ and refluxed for $5 \mathrm{hrs}$. The reaction mixture was left in open dish for 2-3 hrs (Scheme 1).

The solid precipitate formed was filtered, dried and recrystallized from ethanol. The yield of the product \& m.p. was found to be $53.4 \%, 230-232^{\circ} \mathrm{C}$.

\section{Results and Discussions}

\subsection{Spectral data of synthesised compounds}

1-(1-methyl-2-oxo-1,2-dihydroquinolin-4-yl)-2methylphenyl pyrazolidine -3,5-diones $4 a$

IR (KBr): 3086 (Ar, C-H), 2943 (alkenes), 2856 (alkane), 1647 ( $>\mathrm{C}=\mathrm{O}$, quinolone), 1675 ( $>\mathrm{C}=\mathrm{O}$, pyrazolidinedione), $1 \mathrm{H}$ NMR $(\mathrm{CDCl} 3) \quad 2.1 \quad(3 \mathrm{H}$, CH3), $2.8 \quad(3 \mathrm{H}, \quad \mathrm{N}-\mathrm{CH} 3), \quad 3.4 \quad(2 \mathrm{H}$, pyrazolidinedione), 6.86 (1H C3-H quinolone), 7.22-7.26 (8H, Ar) m/z 347 (M+), $349(\mathrm{M}+1)$

1-(1-methyl-2-oxo-1,2-dihydroquinolin-4-yl)-4methylphenyl pyrazolidine -3,5-diones $4 b$

IR (KBr): 3053 (Ar, C-H), 2965 (alkenes), 2847 (alkane), 1650 ( $>\mathrm{C}=\mathrm{O}$, quinolone), $1670(>\mathrm{C}=\mathrm{O}$, pyrazolidinedione), $1 \mathrm{H}$ NMR ( $\mathrm{CDCl} 3) 1.9 \quad(3 \mathrm{H}$, CH3), $2.6 \quad(3 \mathrm{H}, \quad \mathrm{N}-\mathrm{CH} 3), \quad 3.18 \quad(2 \mathrm{H}$, pyrazolidinedione), 6.86 (1H $\mathrm{C} 3-\mathrm{H}$ quinolone), 7.16-7.50 (8H, Ar) m/z $347(\mathrm{M}+)$

1-(1-methyl-2-oxo-1,2-dihydroquinolin-4-yl)-2-

methoxyphenyl pyrazolidine -3,5-diones $4 c$

IR (KBr): 3076,3045 (Ar, C-H), 2935 (alkenes), 2863, 2815 (alkane), 1698 (>C=O, quinolone), 1710 ( $>\mathrm{C}=\mathrm{O}$, pyrazolidinedione), $1115(\mathrm{C}-\mathrm{O}) 1 \mathrm{H} \mathrm{NMR}$ (CDCl3) 2.7 (3H, O-CH3), 2.8 (3H, N-CH3), 3.18 (2H, pyrazolidinedione), 6.50 (1H C3-H quinolone), 7.23-7.78 (8H, Ar) m/z $363(\mathrm{M}+), 364(\mathrm{M}+1)$ 1-(1-methyl-2-oxo-1,2-dihydroquinolin-4-yl)-4methoxyphenyl pyrazolidine -3,5-diones $4 d$

IR (KBr): 3015 (Ar, C-H), 2941 (alkenes), 2887,2851 (alkane), 1690 ( $>\mathrm{C}=\mathrm{O}$, quinolone), 1715 (>C $=\mathrm{O}$, pyrazolidinedione), 1089 (C-O) $1 \mathrm{H}$ NMR (CDCl3) 2.45 (3H, O-CH3), 3.2 (3H, N-CH3), 3.42 (2H, pyrazolidinedione), 6.4 (1 $\mathrm{H} \mathrm{C} 3-\mathrm{H}$ quinolone), 7.1-7.86 (8H, Ar) m/z $363(\mathrm{M}+)$

1-(1-methyl-2-oxo-1,2-dihydroquinolin-4-yl)-2-

chlorophenyl pyrazolidine -3,5-diones $4 e$ IR (KBr): 3082,3045 (Ar, C-H), 2989 (alkenes), 2865 (alkane), $1660 \quad(>\mathrm{C}=\mathrm{O}$, quinolone), 1695 (>C $=\mathrm{O}$, pyrazolidinedione), $756(\mathrm{C}-\mathrm{Cl}) 1 \mathrm{H} \mathrm{NMR}$ 


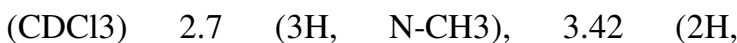
pyrazolidinedione), 6.4 (1H C3-H quinolone), 7.1$8.4(8 \mathrm{H}, \mathrm{Ar}) \mathrm{m} / \mathrm{z} 367(\mathrm{M}+)$

1-(1-methyl-2-oxo-1,2-dihydroquinolin-4-yl)-4chlorophenyl pyrazolidine -3,5-diones $4 f$

IR (KBr): 3074 (Ar, C-H), 2956 (alkenes), 2860, 2812 (alkane), 1667 (>C=O, quinolone), 1686 ( $>\mathrm{C}=\mathrm{O}$, pyrazolidinedione), $760(\mathrm{C}-\mathrm{Cl}) 1 \mathrm{H} \mathrm{NMR}$ $(\mathrm{CDCl} 3) \quad 2.7 \quad(3 \mathrm{H}, \quad \mathrm{N}-\mathrm{CH} 3), \quad 3.42 \quad(2 \mathrm{H}$, pyrazolidinedione), 6.4 (1H C3-H quinolone), 7.1$8.4(8 \mathrm{H}, \mathrm{Ar}) \mathrm{m} / \mathrm{z} 367(\mathrm{M}+), 369(\mathrm{M}+2)$

1-(1-methyl-2-oxo-1,2-dihydroquinolin-4-yl)-2,4

dichlorophenyl pyrazolidine -3,5-diones $4 g$

IR (KBr): 3075, 3068 (Ar, C-H), 2978, 2945

(alkenes), 2845, 2812 (alkane), 1674 (>C=O, quinolone), 1692 (>C=O, pyrazolidinedione), 765 (C-Cl) 1H NMR (CDCl32.7 (3H, N-CH3), 3.42 (2H, pyrazolidinedione), 6.4 (1 $\mathrm{H} \mathrm{C} 3-\mathrm{H}$ quinolone), 7.6-8.86 (7H, Ar) m/z $401(\mathrm{M}+), 403(\mathrm{M}+2), 405$ $(\mathrm{M}+4)$

1-(1-methyl-2-oxo-1,2-dihydroquinolin-4-yl)-2aminophenyl pyrazolidine -3,5-diones $4 h$

IR (KBr): 3456, 3445 (N-H), 3045, 3012 (Ar, C-H), 2963, 2959 (alkenes), 2844, 2836 (alkane), 1690 (>C=O, quinolone), $1705 \quad(>\mathrm{C}=\mathrm{O}$, pyrazolidine dione), $1160(\mathrm{C}-\mathrm{N})$ 1H NMR (CDCl3) $2.7(3 \mathrm{H}, \mathrm{N}-$ $\mathrm{CH} 3), 3.42$ (2H, pyrazolidine dione), $4.5(2 \mathrm{H} \mathrm{NH} 2)$ 6.4 (1H C3-H quinolone), 7.1-7.8 (8H, Ar) m/z 348 $(\mathrm{M}+), 349(\mathrm{M}+1)$

1-(1-methyl-2-oxo-1,2-dihydroquinolin-4-yl)-4aminophenyl pyrazolidine $-3,5$-diones $4 i$

IR (KBr): 3468, 3412 (N-H), 3015 (Ar, C-H), 2948 (alkenes), 2826 (alkane), 1654 ( $>\mathrm{C}=\mathrm{O}$, quinolone), 1723 ( $>\mathrm{C}=\mathrm{O}$, pyrazolidinedione), $1190(\mathrm{C}-\mathrm{N}) 1 \mathrm{H}$ NMR (CDCl3) ) $2.7(3 \mathrm{H}, \mathrm{N}-\mathrm{CH} 3), 3.42(2 \mathrm{H}$, pyrazolidinedione), $4.5(2 \mathrm{H} \mathrm{NH} 2) 6.4(1 \mathrm{H} \mathrm{C} 3-\mathrm{H}$ quinolone), 7.1-7.8 (8H, Ar) m/z $348(\mathrm{M}+)$

\subsection{Biological screenings}

\subsubsection{Animals}

Albino-Swiss mice of either sex weighing (20-25 g) were used for studying in-vivo analgesic activity. Animals were maintained under standard laboratory conditions $\left(24 \pm 2{ }^{\circ} \mathrm{C}\right.$; relative humidity $\left.60-70 \%\right)$.

Study protocol was approved by the institutional Animal Ethics Committee for the Purpose of Control and Supervision on Experiments on Animals (IAEC, Approval No. 1452/PO/a/11/CPCSEA) before experiment. Albino-Swiss mice from Laboratory
Animal House Section, Department of Pharmacology, Devsthali Vidyapeeth College of Pharmacy, Lalpur, Rudrapur (U. S. Nagar) were used in the study. The animals were procured from IVRI, Bareilly (U.P.). Minimum of 6 animals were used in each group.

\subsubsection{Acute Toxicity Studies}

The acute oral toxicity studies were performed to study the acute toxic effects and to determine safest dose of the synthesized compounds. Swiss albino mice of either sex weighing 20-25 g were used for the study. The aqueous solution of compounds were administered orally to different groups of over night fasted mice at the doses of 30,100,300, 1000 and $3000 \mathrm{mg} / \mathrm{kg}$ body weight. After administration of the compounds, animals were observed continuously for the first three hours for any toxic manifestation.

Thereafter, observations were made at regular intervals for $24 \mathrm{hrs}$. Further the animals were under investigation up to a period of one week. $1000 \mathrm{mg} / \mathrm{kg}$ body weight was found to be safe and $1500 \mathrm{mg} / \mathrm{kg}$ body weight was found to be toxic. So dose was decided $1 / 10^{\text {th }}$ of the safe dose i.e. $100 \mathrm{mg} / \mathrm{kg}$ body weight.

\subsubsection{Analgesic Activity \\ Method 1 (Hot Plate Method)}

Heat is used as a source of pain. Animals were individually placed on the hot plate maintain at constant temperature $\left(55^{\circ} \mathrm{C}\right)$ and the reaction of animals, such as paw licking or jump response was taken as the end response.

Analgesic drugs/compounds increases the reaction time. The method was first described by Eddy $\&$ Leimbach (A cut off period of $15 \mathrm{sec}$ is observed to avoid damage to the paw). The compounds were dissolved in the Carboxy Methyl Cellulose $(0.5 \%$ suspension) Control, standard and test compounds were given per orally to the animals and the reaction of time of animals at $30,60,90 \& 120$ min interval was noted on the hot plate after drug administration.

The method of Eddy and Leimbach using techno heated plat analgesic apparatus was used. The standard drug Diclofenac Sodium $(20 \mathrm{mg} / \mathrm{kg}$ ) was used reference drug for comparison. The result was tabulated in Tables 1 \& 2. Results were expressed as means \pm S.E.M. Statistical significance was analyzed using the one-way analysis of variance followed by 
Tukey's Multiple Comparison Test where $\mathrm{p}<0.05$ was accepted to be a significant difference.

Table 1. Effect of synthesized compounds on latency to hot plate test in mice

\begin{tabular}{|c|c|c|c|c|c|}
\hline \multirow[t]{2}{*}{$\begin{array}{l}\text { Treatme } \\
\text { nts }\end{array}$} & \multicolumn{5}{|c|}{$\begin{array}{l}\text { Mean latency(s) before and after drug } \\
\text { administration(s) }\end{array}$} \\
\hline & $0 \mathrm{~min}$. & $30 \mathrm{~min}$. & $60 \mathrm{~min}$. & 90 min. & $120 \mathrm{~min}$. \\
\hline Control & $\begin{array}{l}2.13 \pm \\
0.219\end{array}$ & $\begin{array}{l}2.13 \pm \\
0.228\end{array}$ & $\begin{array}{l}2.13 \pm \\
0.187\end{array}$ & $\begin{array}{l}2.20 \pm \\
0.241\end{array}$ & $\begin{array}{l}2.23 \pm \\
0.227\end{array}$ \\
\hline $\begin{array}{l}\text { Diclofe } \\
\text { nac } \\
\text { sodium }\end{array}$ & $\begin{array}{l}2.32 \pm \\
0.098 * * \\
*\end{array}$ & $\begin{array}{l}5.64 \pm \\
0.678 * * \\
*\end{array}$ & $\begin{array}{l}8.46 \pm \\
0.647 * * \\
*\end{array}$ & $\begin{array}{l}11.04 \pm 0 \\
.507 \\
* * *\end{array}$ & $\begin{array}{l}13.47 \pm 0.7 \\
96 * * *\end{array}$ \\
\hline $\begin{array}{l}\text { QAA- } \\
04 \mathrm{a}\end{array}$ & $\begin{array}{l}2.310 \pm \\
0.073 \\
* * *\end{array}$ & $\begin{array}{l}5.23 \pm \\
0.164 \\
* * *\end{array}$ & $\begin{array}{l}7.80 \pm \\
0.758 * * \\
*\end{array}$ & $\begin{array}{l}10.23 \pm \\
0.419 \\
* * *\end{array}$ & $\begin{array}{l}12.24 \pm \\
0.173 * * *\end{array}$ \\
\hline $\begin{array}{l}\text { QAA- } \\
04 \mathrm{~b}\end{array}$ & $\begin{array}{l}2.26 \pm 0 \\
186^{*}\end{array}$ & $\begin{array}{l}4.26 \pm 0 \\
685 * *\end{array}$ & $\begin{array}{l}7.50 \pm \\
0.587 * *\end{array}$ & $\begin{array}{l}9.58 \pm 0 \\
087 *\end{array}$ & $\begin{array}{l}11.43 \pm 0.0 \\
98 * *\end{array}$ \\
\hline $\begin{array}{l}\text { QAA- } \\
04 \mathrm{c}\end{array}$ & $\begin{array}{l}2.24 \pm 0 \\
635^{*}\end{array}$ & $\begin{array}{l}5.74 \pm 1 \\
02 *\end{array}$ & $\begin{array}{l}8.65 \pm 0 \\
205^{* *}\end{array}$ & $\begin{array}{l}11.56 \pm 1 \\
.29 * * *\end{array}$ & $\begin{array}{l}13.62 \pm 0.1 \\
16^{* * *}\end{array}$ \\
\hline $\begin{array}{l}\text { QAA- } \\
04 d\end{array}$ & $\begin{array}{l}2.12 \pm 0 \\
567 * * *\end{array}$ & $\begin{array}{l}5.40 \pm 0 . \\
660 * * *\end{array}$ & $\begin{array}{l}8.82 \pm 1 \\
150 * * *\end{array}$ & $\begin{array}{l}11.70 \pm 0 \\
.107 * * *\end{array}$ & $\begin{array}{l}13.49 \pm 0.1 \\
88 * * *\end{array}$ \\
\hline $\begin{array}{l}\text { QAA- } \\
04 \mathrm{e}\end{array}$ & $\begin{array}{l}2.18 \pm 1 \\
10^{*}\end{array}$ & $\begin{array}{l}4.88 \pm 0 \\
402 * *\end{array}$ & $\begin{array}{l}6.08 \pm 0 \\
038 * *\end{array}$ & $\begin{array}{l}9.56 \pm 0 \\
123 * * \\
\end{array}$ & $\begin{array}{l}11.42 \pm 1.3 \\
4 * * *\end{array}$ \\
\hline $\begin{array}{l}\text { QAA- } \\
04 \mathrm{f}\end{array}$ & $\begin{array}{l}2.34 \pm 1 \\
276^{* *}\end{array}$ & $\begin{array}{l}5.36 \pm 1 \\
47 * *\end{array}$ & $\begin{array}{l}8.45 \pm .0 \\
76^{* *}\end{array}$ & $\begin{array}{l}10.56 \pm 0 \\
.250 * * \\
\end{array}$ & $\begin{array}{l}12.96 \pm 0.3 \\
76 * * *\end{array}$ \\
\hline $\begin{array}{l}\text { QAA- } \\
04 \mathrm{~g}\end{array}$ & $\begin{array}{l}2.26 \pm 0 \\
602 * *\end{array}$ & $\begin{array}{l}5.25 \pm 1 \\
102\end{array}$ & $\begin{array}{l}8.45 \pm 0 \\
406 * *\end{array}$ & $\begin{array}{l}10.23 \pm 0 \\
.312 * * \\
\end{array}$ & $\begin{array}{l}12.89 \pm 0.0 \\
92 * * *\end{array}$ \\
\hline $\begin{array}{l}\text { QAA- } \\
04 \mathrm{~h}\end{array}$ & $\begin{array}{l}2.35 \pm 0 . \\
403 * *\end{array}$ & $\begin{array}{l}4.62 \pm 0 \\
610\end{array}$ & $\begin{array}{l}7.85 \pm 0 . \\
814\end{array}$ & $\begin{array}{l}9.78 \pm 0 \\
664 * * *\end{array}$ & $\begin{array}{l}11.78 \pm 1.3 \\
5\end{array}$ \\
\hline $\begin{array}{l}\text { QAA- } \\
04 \mathrm{i}\end{array}$ & $\begin{array}{l}2.41 \pm 1 \\
076^{* *}\end{array}$ & $\begin{array}{l}5.17 \pm 0 . \\
724 * * *\end{array}$ & $\begin{array}{l}8.23 \pm 0 . \\
610 * *\end{array}$ & $\begin{array}{l}10.36 \pm 0 \\
.036^{* *}\end{array}$ & $\begin{array}{l}12.56 \pm 0.4 \\
46 * * *\end{array}$ \\
\hline
\end{tabular}

Two- way Analysis of Variance: ***p value found to be $<0.0001$ is considered extremely significant. The data were expressed as mean \pm S.E.M.; Tukey Kramer multiple comparison test: $* * \mathrm{p}<0.001 \& * \mathrm{p}<0.05$ (Compounds vs. control)

\section{Method 2 (Acetic Acid Induced writhing test)}

The analgesic activity of the extracts was evaluated using acetic acid induced writhing method in mice. In this method, acetic acid is administered intra-peritoneally to the experimental animals to induce pain sensation. Albino mice of either sex (25$30 \mathrm{~g}$ ) were used for the study. In the present study diclofenac sodium was used to as standard.

Test samples and vehicle were administered orally 30 minutes prior to intraperitoneal administration of $0.6 \% \mathrm{v} / \mathrm{v}$ acetic acid solution $(0.1 \mathrm{ml} / 10 \mathrm{~g})$ but diclofenac sodium $(20 \mathrm{mg} / \mathrm{kg})$ under same condition was administered 30 minutes prior to acetic acid injection. Then the animals were placed on an observation table. Each mouse of all groups were observed individually for counting the number of writhing they made in 20 minutes commencing just 5 minutes after the intra-peritoneal administration of acetic acid solution.

Table2. Effect of synthesized compounds on acetic acid induced writhing in mice $\mathrm{N}=6 ; \quad$ student $\mathrm{t} \quad$ test; ${ }^{*} \mathrm{P} \leq 0.05 ; \quad * * \mathrm{P} \leq 0.01$; ***

\begin{tabular}{|l|l|l|l|l|}
\hline $\begin{array}{c}\text { S. } \\
\text { No. }\end{array}$ & Derivative & Dosage & $\begin{array}{c}\text { No. of writhings in } \\
\text { 20 min (mean } \pm \\
\text { S.E.M })\end{array}$ & $\begin{array}{c}\text { Analgesic } \\
\text { Activity } \\
\%\end{array}$ \\
\hline 1 & Control & Vehicle & $42.3 \pm 0.223607$ & 0 \\
\hline 2 & QAA-04a & $20 \mathrm{mg} / \mathrm{kg}$ & $9.1 \pm 0.341565^{* * *}$ & 78.49 \\
\hline 3 & QAA-04b & $20 \mathrm{mg} / \mathrm{kg}$ & $10.5 \pm 0.288675^{* * *}$ & 63.12 \\
\hline 4 & QAA-04Jc & $20 \mathrm{mg} / \mathrm{kg}$ & $15.6 \pm 0.341565 * * *$ & 63.19 \\
\hline 5 & QAA-04d & $20 \mathrm{mg} / \mathrm{kg}$ & $9.1 \pm 0.74162^{* *}$ & 79.18 \\
\hline 6 & QAA-04e & $20 \mathrm{mg} / \mathrm{kg}$ & $12 \pm 0.619139 * *$ & 73.34 \\
\hline 7 & QAA-04f & $20 \mathrm{mg} / \mathrm{kg}$ & $10.5 \pm 1.204159^{* *}$ & 75.88 \\
\hline 8 & QAA-04g & $20 \mathrm{mg} / \mathrm{kg}$ & $11.9 \pm 0.67082$ & 71.87 \\
\hline 9 & QAA-04h & $20 \mathrm{mg} / \mathrm{kg}$ & $11.6 \pm 0.341565 * * *$ & 72.57 \\
\hline 10 & QAA-04i & $20 \mathrm{mg} / \mathrm{kg}$ & $15.2 \pm 0.465475$ & 64.06 \\
\hline 11 & $\begin{array}{l}\text { Diclofenac } \\
\text { Sodium }\end{array}$ & $20 \mathrm{mg} / \mathrm{kg}$ & $7.1 \pm 0.223607 * * *$ & 83.21 \\
\hline
\end{tabular}

$\mathrm{P} \leq 0.0001$ when compared with control.

$$
\text { Analgesic activity }=\frac{N_{C}-N_{t}}{N_{C}} \times 100
$$

$\mathrm{N}_{\mathrm{c}}$ - No. of writhings for control

$\mathrm{N}_{\mathrm{t}}$ - No. of writhings for test compound

Control animals received an equal volume of vehicle. Results of percentage analgesic activity of compounds were calculated using following formula and the results were show in Table 2.

Fig.2 shows comparative effect of synthesized compounds on latency to hot plate test in mice and in Fig.3 the comparative effect of synthesized compounds on acetic acid induced writhing in mice is presented. 


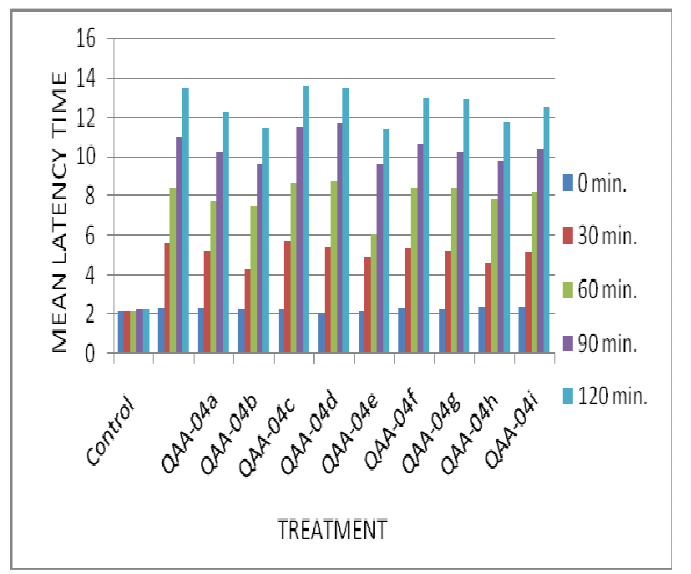

Fig.2. Comparative effect of synthesized compounds on latency to hot plate test in mice.

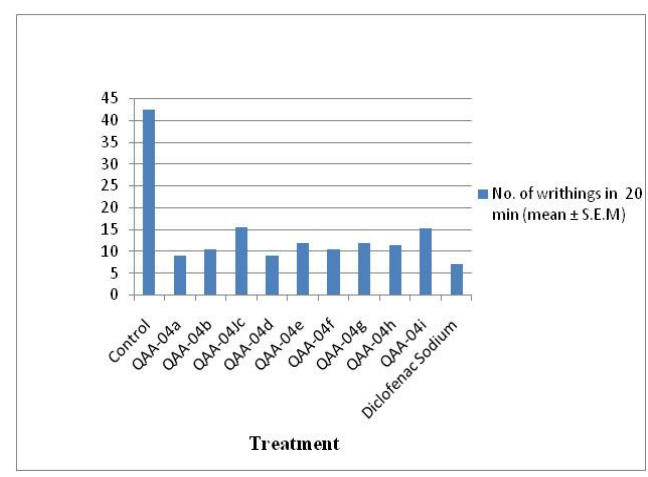

Fig.3. Comparative effect of synthesized compounds on acetic acid induced writhing in mice

The present work has clearly demonstrated that 2quinolone moiety can be successfully used to synthesize a wide variety of pyrazolidine 3,5 dione derivatives of pharmaceutical interest. A novel series of compounds (QAA-04a-04i) were synthesized and characterized by their IR and NMR data and mass data. All the synthesized compounds were subjected to the acute toxicity studies and their analgesic activity.

The activity is done by hot plate method which is further confirmed by acetic acid induced writhing method. Results of analgesic activity via hot plate model showed that compound QAA-04a, QAA-04c, QAA-04d, QAA-04f, QAA-04g and QAA-04i were found to possess a significant analgesic activity and comparable to the standard drug when compared to the control. Compounds QAA-04c, QAA-04d were found to posses the significant after $30 \mathrm{~min}$. When compared with standard the compounds QAA-04c and QAA-04d found to possess a very significant activity (Table 1).

Hot plate method is an acute spinally mediated reflex to noxious thermal stimuli and it is known to be selective for centrally acting analgesics. In this model compound QAA-04c, QAA-04d, QAA-04f and QAA$04 \mathrm{~g}$ were found to posses significant analgesic activity and comparable to the standard drug [26-28].

Mechanism of action of compounds could probably due to blockade of the effect or the release of endogenous substances that excite pain nerve endings similar to that of diclofenac sodium and other NSAIDs. This is because NSAIDs can inhibit COX in peripheral tissues and, therefore, interfere with the mechanism of transduction of primary afferent nociceptors [29-32].

Acetic acid causes inflammatory pain by inducing capillary permeability and liberating endogenous substances that excite pain nerve endings. Since the writhing test usually lasts for less than one hour, it is too short to cover central prostaglandin-dependent sensitization, which requires spinal COX-2 induction. However it primarily involves $\mathrm{COX}-1$ derived prostanoids and thus non selective COX inhibitors offers a better anti-nociceptive effect as compared to selective COX-2 inhibitors [33-35].

All compounds have shown analgesic activity. Our study revealed the anti-nociceptive potential of synthesized compounds QAA-04a and QAA-04d produced significant inhibition in acetic acid writings, p.o. suggesting peripheral analgesic activity. In this model compound QAA-04a, QAA-04d, QAA-04e and QAA-04f were found to posses significant analgesic activity and comparable to the standard drug.

\section{Conclusions}

From the above study it was concluded that, among the series of tested derivatives, the good analgesic activity was given by the compounds substituted with electron donating groups where as the compounds substituted with electron withdrawing groups have moderate analgesic activities. In case of hot plate model compounds QAA-04c and QAA-04d have given more activity than standard, whereas in case of acetic acid induced writhing model compounds QAA-04a and QAA-04d have given 
significant analgesic activity which is comparable with the standard drug.

\section{Acknowledgments}

The authors are thankful to Devsthali Vidyapeeth College of Pharmacy, Lalpur, Rudrapur (U. S. Nagar), Sophisticated Analytical Instrument Facilities, Punjab University, Chandigarh for providing IR, ${ }^{1} \mathrm{HNMR}$ and mass spectra.

\section{References}

*Email : abhishekt1983@gmail.com

[1] VT. Andriole. The Quinolones. $2^{\text {nd }}$ ed. Academic Press San Diago, California (USA). p.2, 24-25 (2006).

[2] CS Jia, YW Dong, SJ Tu and GW Wang. Tetrahedron 63, 892-897 (2007).

[3] Marcaccini S, Pepino R, Pozo MC, Basurto S, Valverde MG and Torroba T. Tetrahedron Lett 45, 3999-4001 (2004).

[4] WMF Fabian, KS Niederreiter, G Uray and WJ. Stadlbauer, Mol Str. 477, 209-220 (1999).

[5] RG. Kalkhambkar, GM. Kulkarni, WS. Hwang and CS. Lee. Anal Sci 23, 145-146 (2007).

[6] Yet L: 4.01-Pyrazoles. Elsevier: Oxford, 1-141 (2008).

[7] Williams M, Kowaluk EA and Arneric SP. J Med Chem 42, 1481-1500 (1999).

[8] SR. Pattan, PA. Rabara, JS. Pattan, AA. Bukitagar, VS. Wakale VS and DS. Musmade. Indian J Chem 48B, 1453-1456 (2009).

[9] SR. Shih, TY. Chu, G. Reddy, SN. Tseng, HL. Chen, WF. Tang, MS. Wu, JY. Yeh, YS. Chao, J. Hsu, HP. Hsieh and JT. Horng. J Biomed Sci. 17(1), 13 (2010).

[10]HY. Lo, CC. Man, RW. Fleck, NA. Farrow, RH. Ingraham, A. Kukulka A, JR. Proudfoot, R. Betageri, T. Kirrane, U. Patel, R. Sharma, MA. Hoermann, A. Kabcenell and SD. Lombaert, Bioorg Med Chem Lett. 20(22), 6379-6383 (2010).

[11] R. Kasımogullari, M. Bulbul, BS. Arslan and B. Gokçe Eur J Med Chem, 46(10), 5034-5038 (2011).

[12] N. Gokhan-Kelekci, S. Koyunoglu, S. Yabanoglu, Yelekci K, O. Ozgen, G. Ucar, K. Erol, E. Kendi and A. Yesilada, Bioorg Med Chem Lett 17(2), 675-689 (2009).
[13] A. Tanitame, Y. Oyamada, K. Ofuji, H. Terauchi, M. Kawasaki, M. Wachi and JI. Yamagishi, Bioorg Med Chem Lett. 15(19), 4299-4303 (2005).

[14] VK. Tandon, DB. Yadav, AK. Chaturvedi and PK. Shukla, Bioorg Med Chem Lett. 15(13), 3288-3291 (2005).

[15] Shen DM et al. Bioorganic \& Medicinal Chemistry Letters 21(1), 76-81(2011).

[16]LW. Zheng, J. Zhu, BX. Zhao, YH. Huang, J. Ding and JY. Miao, Eur J Med Chem, 45(12), 5792-5799 (2010).

[17] M. Chioua, A. Samadi, E. Soriano, O. Lozach, L. Meijer and M. Contelles J. Bioorg Med Chem Lett. 19(16), 4566-4569 (2009).

[18] YM Litvinov, AA Shestopalov, LA Rodinovskaya and AM Shestopalov. J Combi Chem 11(5), 914-919 (2009).

[19] Y Li, D Hong, P Lu and Y Wang. Tetrahedron Lett, 52(32), 4161-4163 (2011).

[20]RV. Ragavan, V. Vijayakumar V and NS. Kumari. Eur J Med Chem 45(3), 1173-1180 (2010).

[21]P. Roschger, W. Fiala and W. Stadlbauer. J. Heterocycl. Chem. 29, 225-231 (1999).

[22] W. Fiala and J. Stadlbauer. J. Prakt. Chem 335, 128-134 (1993).

[23] TI. El-Emary, J. Chin. Chem. Soc. 53, 391 (2006).

[24] MB. Deshmukh, SS. Jagtap and SA. Deshmukh, J. Indian Chem.Soc. 83, 1055 (2006).

[25] V. Sharma and KV. Sharma. E-Journal Chem 6(2), pp.356-384 (2006).

[26] A. Elsayed Rashed, AH. Shamroukh, MI. Hegab and H.M. Awad. Acta Chim. Slov. 52, 429-434 (2005).

[27] O. Migliara, D. Raffa, S. Plescia, MG. Gusimano, and A. Carbone, Arkivoc II, 1-10 (2009).

[28] M. Ahmed, SK. Sadhu , BK. Dutta, JK. Kunu and SC. Bachar, Pharmazie 52, 472 (1997).

[29]FA. Santos and VSN. Rao, Phytother Res. 14, 240 (2000).

[30] SK. Lee, CH. Hong, SK. Huh, SS. Kirn, Oh OJ, HY Min, KK Park, WY Chuang and JK Wang, J Env Path Toxicol Oncology 21,141 (2002).

[31]JH. Yoon, HJ. Lim, HJ. Lee, K. Hee-doo, J. Raok and R. Jaeha, Bioorg Med Chem Letters 18, 2179 (2008). 
[32] A. Salminen, M. Lehtonen, T. Suuronen and K. [34]T. Taesotikul, A. Panthong, D. Kanjanapothia, R. Kaarniranta \& Huuskonen, J. CMLS 65, 2979 (2008). Verpoorteb and JJC. Schefferb, J Ethnopharmacol 84(1), 31-35(2003).

[33] SW. Hajare, S. Chandra, SK. Tandan, J. Sharma, J. Lal and AG. Telang, Indian J Pharmacol 32, 357-60 (2006).

[35]S. Golshani, F. Karamkhani, HR. MonsefEsfahani, M. Abdollahi M. J. Pharm. Pharmaceut. Sci., 7(1): $76-79$ (2004). 